The LD50 of diquat is only half of that of paraquat, but nevertheless, the occurrence of diarrhoea, and the persistence of the poison for such a long period in the patient's urine would suggest that a considerable amount of diquat had been swallowed, rather more perhaps than the quantities of paraquat involved in those cases which have been reported to date. One case of paraquat poisoning has already been reported with successful treatment by forced diuresis (Kerr et al., 1968) so that it is not improbable that this form of treatment may have contributed materially to the outcome of our case. Steroids were not given since there is no strong evidence to support their effectiveness in these patients. Both peritoneal and haemodialysis have been suggested as methods of removing paraquat from the body, but in view of the evidence that this patient was excreting diquat in the urine and the ease with which he maintained such an enormous diuresis, it was decided to persist with this single form of treatment.

\section{Acknowledgment}

We are grateful to Mr Carson of the Forensic Science Laboratory, Belfast, who carried out the diquat estimations.

\section{References}

Barnes, J.M. (1968) Poisons that hit and run. New Scientist, 38, 619.

CAmprell, S. (1968) Death from paraquat in a child. Lancet, i, 144.

DANiel, J.W. \& GAGE, J.C. (1966) Absorption and excretion of diquat and paraquat in rats. Brit.J. industr. Med. 23, 133.

KerR, F., Patel, A.R., Scott, P.D.R. \& Tompsett, S.L. (1968) Paraquat poisoning treated by forced diuresis. Brit. med. J. 3, 290.

Matthew, H., Logan, A., Woodruff, M.F.A. \& Heard, B. (1968) Paraquat poisoning-lung transplantation. Brit. med. J. 3, 759.

Oreopoulos, D.G., Soyannwo, M.A.O., Sinniah, R., Fenton, S.S.A, MCGeown, M.G. \& BRUCE, J.H. (1968) Acute renal failure in a case of paraquat poisoning. Brit. med. J. 1, 749.

\title{
Congenital, sporadic dysgammaglobulinaemia (absence of IgA and partial deficit in IgG and IgM)
}

\author{
L. A. SCURO \\ M.D. \\ S. TODESCO
}

Institute of Medical Pathology of the University of Padua; and Institute of Laboratory Medicine of the University of Genoa, Italy
Clinical syndromes associated with immunoglobulin deficiency (hypogammaglobulinaemia) are being observed more and more often (Marie et al., 1965; Andolfatto Zaglia \& Gasparotto, 1966; Israel Asselain et al., 1966). On the other hand, a selective deficit in a single immunoglobulin fraction (dissociated deficiency) is rarely found (Werner et al., 1965; Leveque, 1965; Israel Asselain et al., 1966).

Recently we have observed a young woman afflicted with repeated respiratory infections from the age of 6 months. Examination of the immunoglobulins showed an absence of IgA accompanied by a partial deficit in IgG and IgM. We believe the case merits mention not only for its rarity, but also because it affords a basis for consideration of the biological significance of the $\gamma \mathrm{A}$-immunoglobulins.

\section{Case report}

F.B., 12 years of age. Family history: a maternal aunt was affected with pulmonary tuberculosis. The parents and five siblings are healthy. The patient was breast-fed for 3 months and appeared to have had a normal psychosomatic development. Menstruation began several days after her first recovery in our Institute in October 1965.

From the first weeks of life the patient was affected with a persistent cough and at 9 months underwent her first of eleven subsequent hospitalizations for bronchopneumonia. After several months she was transferred to a sanatorium where she remained until 4 years of age, frequently suffering from highly febrile bouts of non-tuberculous bronchopneumonia. In the following years the same pattern recurred, with infections always exclusively involving the respiratory system. During these febrile bouts the sputum was frequently mucopurulent. Morning vomiting was common.

At 8 years of age the patient had a negative Mantoux reaction and a normal blood picture. At 9 years old, during one of her numerous hospitaliza- 
tions, bronchoscopy and bronchography were carried out which showed the presence of bronchiectasis in the middle right lobe.

Subsequent hospitalization followed annually and the patient was admitted to our Institute for the first time on 30 October 1965 because of a chest infection. Her skin was pale. There was no clubbing. The submandibular and cervical lymph nodes were enlarged, pea-sized and not tender. The interorbital and right maxillary areas were tender. The oropharynx was slightly congested and the tonsils showed chronic inflammation. There was evidence of rhinitis and sinusitis. Movement and tactile fremitus were reduced at the bases, with crepitations on inspiration. The heart was not enlarged; there was an increased pulmonary second sound. The liver and spleen were slightly enlarged.

\section{Investigations}

Chest X-ray and tomography (November 1965) showed a triangular opacity in the right middle lobe bordered by the major fissure, and a triangular opacity in the left lower lobe (Fig. 1). Bronchography

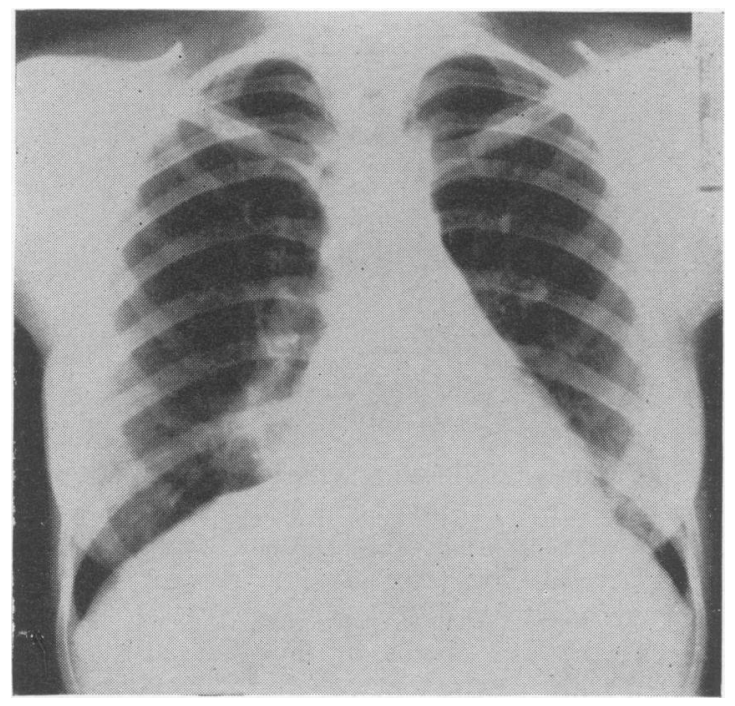

FIG. 1. Radiography of the thorax. Triangular opacity corresponding to the right middle lobe.

showed crowding of the bronchi in the lingula with bronchiectasis there and in the left lower lobe and in the right middle and lower lobes.

Respiratory function tests: Marked reduction in vital capacity without an increase in residual air. Normal Tiffeneau index; ventilatory reserve within normal limits. The spirometric indices give evidence of a moderately severe ventilat ory insufficiency of an obstructive type.
Sputum culture: Repeated tests showed the presence of Gram-negative organisms, negative for Koch bacillus. Sweat test: negative (Na $106 \mathrm{mEq} / \mathrm{l}, \mathrm{K} 20$ $\mathrm{mEq} / \mathrm{l}, \mathrm{Cl} 50 \mathrm{mEq} / \mathrm{l})$.

\section{Schwachman test : Negative, Congo-red test $:$ Nega- tive.}

Skull $X$-rays: Paranasal sinuses of average development for the age; the right frontal sinus smaller than the other. Thickening of the mucosa of the maxillary sinuses more on the left where the antrum is almost completely filled.

Blood: Hb, 75\%; PVC, $40.5 \%$; RBC, 4,950,000 $\mathrm{mm}^{3}$; WBC, $10,670 \mathrm{~mm}^{3}$. Differential: neutrophils, $59 \%$; basophils, $0 \%$; eosinophils, $5 \%$; lymphocytes, $30 \%$; monocytes, $6 \%$; ESR 8.5 (Katz index). Blood sugar: $90 \mathrm{mg} / 100 \mathrm{ml}$; BUN, $18 \mathrm{mg} / 100 \mathrm{ml}$. Serum bilirubin: $0.32 \mathrm{mg} / 100 \mathrm{ml}$ (total-indirect). Serum flocculation: Takata, 70; MacLagan, 0.40; Kunkel, 0.60; WW, negative; ASOT, $166 \mathrm{U} / \mathrm{ml}$. Intradermal tuberculin reaction $(1: 10,000$ dilution): negative after 24 and $48 \mathrm{hr}$. Total protein, $5.6 \mathrm{~g} / 100 \mathrm{ml}$;

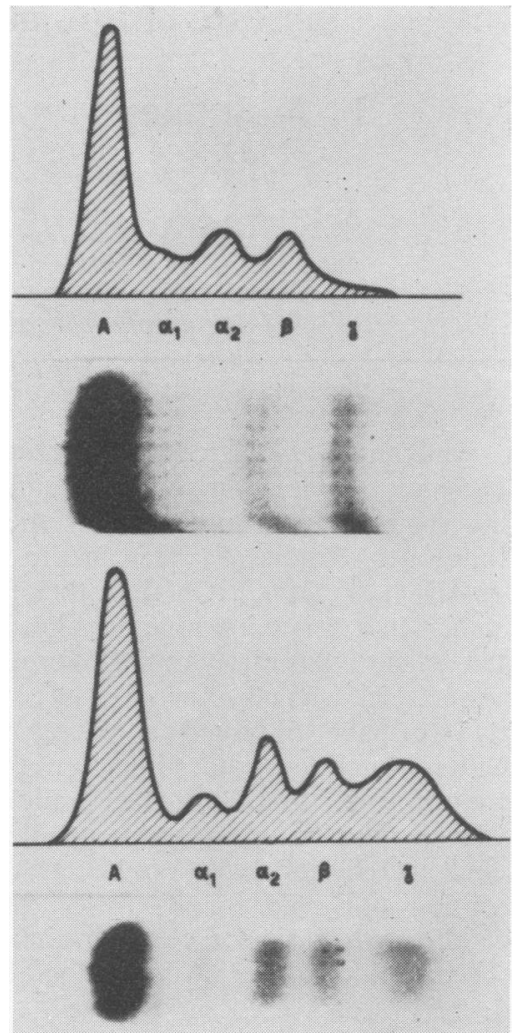

FIG. 2. Electrophoresis on paper of the serum proteins. Almost total absence of the band corresponding to the $\gamma$-globulin fraction. Normal findings below. 
TABLE 1. Serum protein values

\begin{tabular}{|c|c|c|c|c|c|c|c|}
\hline & \multicolumn{3}{|c|}{ Prior to vaccine stimulus } & \multirow[b]{2}{*}{12 January } & \multirow[b]{2}{*}{31 March } & \multicolumn{2}{|c|}{ After vaccine stimulus } \\
\hline & 9 November & 20 November & 18 December & & & 24 April & 7 May \\
\hline $\begin{array}{l}\text { Total } \\
\text { Albumin }(\%) \\
\alpha_{1} \text {-Globulin } \\
\alpha_{2} \text {-Globulin } \\
\beta \text {-Globulin } \\
\gamma \text {-Globulin }\end{array}$ & $\begin{array}{c}4.90 \\
61 \cdot 00 \\
5 \cdot 6 \\
16 \cdot 3 \\
14 \cdot 5 \\
2 \cdot 6\end{array}$ & $\begin{array}{c}4 \cdot 70 \\
76 \cdot 90 \\
5 \cdot 2 \\
7 \cdot 7 \\
9.3 \\
1 \cdot 9\end{array}$ & $\begin{array}{c}4 \cdot 70 \\
54 \cdot 90 \\
7 \cdot 5 \\
15 \cdot 5 \\
18 \cdot 8 \\
3 \cdot 3\end{array}$ & $\begin{array}{c}6 \cdot 60 \\
62 \cdot 20 \\
5 \cdot 6 \\
12 \cdot 8 \\
13 \cdot 8 \\
5 \cdot 6\end{array}$ & $\begin{array}{c}7 \cdot 00 \\
47 \cdot 70 \\
8 \cdot 3 \\
14 \cdot 5 \\
16 \cdot 6 \\
12 \cdot 9\end{array}$ & $\begin{array}{c}5 \cdot 80 \\
55 \cdot 00 \\
6 \cdot 6 \\
16 \cdot 9 \\
16 \cdot 3 \\
5 \cdot 2\end{array}$ & $\begin{array}{c}5 \cdot 80 \\
52 \cdot 40 \\
9 \cdot 2 \\
15 \cdot 5 \\
16 \cdot 6 \\
6 \cdot 4\end{array}$ \\
\hline
\end{tabular}

albumin, $3.93 \mathrm{~g}$; globulin, $1.68 \mathrm{~g} / 100 \mathrm{ml}$. A/G ratio: 2.9 (albumin, 70\%; $\alpha_{1}$-globulin, $2.6 \% ; \alpha_{2}$-globulin, $9.6 \% ; \beta$-globulin, $15.4 \%$ and $\gamma$-globulin, $2.4 \%$ ) (paper electrophoresis, Fig. 2).

The serum protein response to anti-tetanus vaccine stimulus (two injections at an interval of 10 days was studied, with controls) (Table 1).

Immunoelectrophoresis: The $\gamma \mathrm{A}$-globulin fraction was absent while the $\gamma \mathrm{G}$ and $\gamma \mathbf{M}$ fractions were lowered (Fig. 3).
Radial immunodiffusion (Fahey's method for quantitative determination): IgG, $210 \mathrm{mg}$; IgM, 45 $\mathrm{mg}$ and $\mathrm{IgA}, 20 \mathrm{mg} / 100 \mathrm{ml}$.

Serum immunoelectrophoresis on the parents and five siblings: one brother (15 years old) showed a modest reduction in IgA.

Immunofluorescence on tonsil sections treated with specific anti-sera: fluorescence within normal limits with anti-IgG serum, no fluorescence with anti-IgA serum.

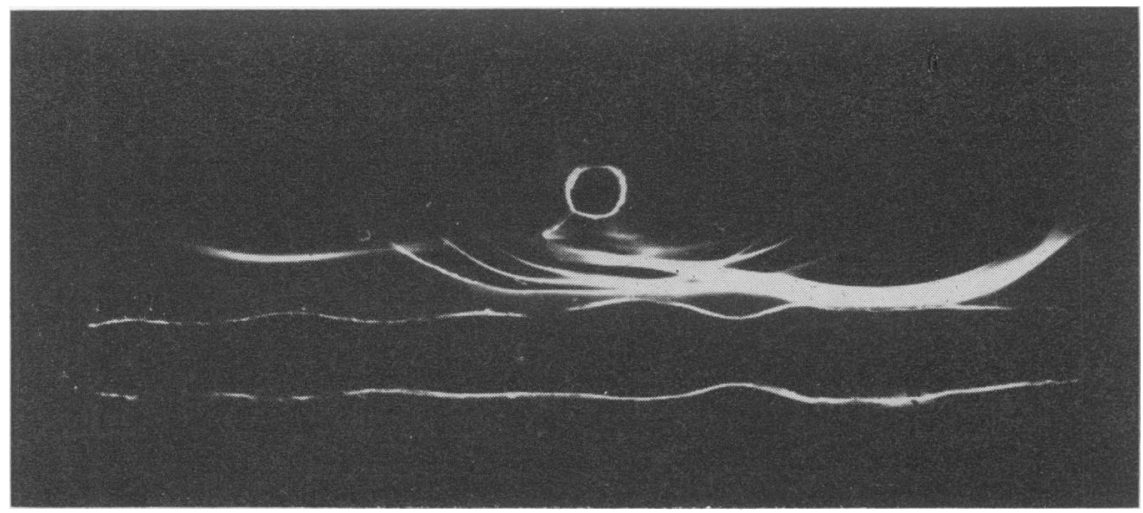

FIG. 3. Immunoelectrophoresis. Diminution of the IgG and IgM fractions and absence of the IgA fractions.

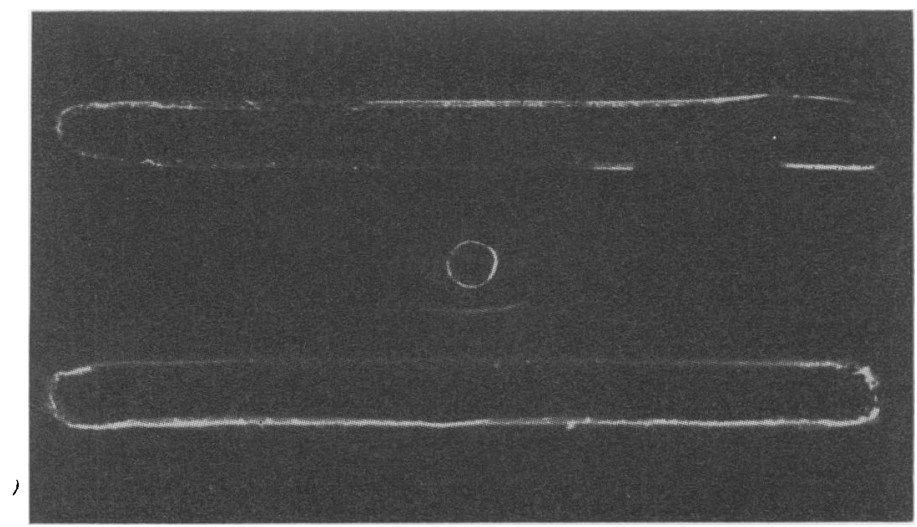

FIG. 4. Immunoelectrophoresis with IgA and IgM antisera. Absence of the line of precipitation of IgA (top) and presence of slight precipitation bands of IgM (bottom). 
Blood type: type $\mathrm{O} \mathrm{Rh}$ positive, CcDdee Blood complement $33 \mathrm{U} / \mathrm{ml}$. Indirect and direct Coombs' test, negative. Haemagglutin tests cold and warm, negative.

\section{Discussion}

There is no doubt that in this case a close relationship exists between the immunoglobulin deficiency and the repeated respiratory infection, as in other previously reported cases (Migueres et al., 1965; Gugler \& Barandum, 1966; Israel Asselain et al., 1966; Pernod \& Kermarec, 1966; Pernod et al., 1966). It is also certain that the bronchiectasis arose secondarily since its appearance was observed first on the right and then on the left. The occurrence of symptoms only 6 months after birth suggests the preexistence of an immunological deficit.

However, the lack of familial involvement is in favour of a sporadic congenital form, according to the classification of Petersen, Cooper \& Good (1965).

Qualitative and quantitative studies on serum immunoglobulin as well as those of immunofluorescence carried out on tonsil sections have shown an absence of IgA accompanied by a partial deficit in IgG and IgM. Thus, the case falls within the class of the rare so-called 'dissociated deficiencies' of immunoglobulins, likewise called 'atypical hypogammaglobulinaemia'. Up until now the following types have been observed:

(1) Deficit in IgG and IgA with an increase in IgM (Good \& Zack, 1956; Israel Asselain, Burtin \& Chebat, 1960; Heremans, 1960).

(2) Deficit in $\operatorname{IgA}$ and $\operatorname{IgM}$ with normal IgG Heremans, 1960; Pena Guitian, Varela Bujan \& Gomez Vidal, 1963; Berheim et al., 1964; Marano et al., 1966).

(3) Deficit in IgA alone (Rosen \& Bougas, 1963; Crabbe \& Heremans, 1967).

Leveque (1965) considers that the latter, even though it has been observed in numerous children affected with repeated infections, can not yet be elevated to the category of a well-defined syndrome. Lending support to this, Bachman (1965) and Rockey et al., (1964) have found an absence of $\operatorname{IgA}$ in, respectively, one and two apparently normal subjects. Others, however, have discovered this immunological deficit in children with the ataxiatelangiectasia syndrome, and more recently, Crabbe \& Heremans (1967) have reported three cases of steatorrhea with selective absence of IgA, believing that malabsorption in this syndrome can lead to an immunological disorder; however, no pathogenetic mechanism for this was suggested.

It is probable that the isolated absence of $\operatorname{IgA}$ can cause symptoms, especially when it is associated with a partial deficit in the other immunoglobulins, in particular that of IgG, as in this case. A more pro- found and systematic study of patients with repeated infective manifestations, mainly of the respiratory or gastro-intestinal tracts, would provide a stronger basis for this hypothesis. A more exact evaluation would then be possible of the biological significance of the $\gamma \mathrm{A}$-immunoglobulins, or, as they are called by Heremans, Crabbe \& Mason (1966), since they are present in higher concentrations in exocrine secretions than in serum, the 'exocrine immunoglobulins'.

Our first observations as well as those of others seem to confirm the hypothesis that the $\gamma$ A-immunoglobulins have a protective function on mucous membranes, especially those of the respiratory tract. The reasons why the selective deficit of $\operatorname{IgA}$ is associated with isolated manifestations in both the respiratory and digestive systems remain unknown.

\section{References}

Andolfatto Zaglia, G. \& Gasparotto, G. (1966) Le sindromi da deficienza immunologica-vedute attuali. Acta med. Patavina, 26, 1.

BACHMANN, R. (1965) Studies on the serum $\gamma$ A-globulin level. III. The frequency of a $\gamma \mathrm{A}$-globulinemia. Scand. J. clin. Lab. Invest. 17, 316.

Bernheim, M., Francois, R., Larbre, F., Rosemberg, D., Creyssler, R., Manuel, Y. \& Freycon, M. T. (1964) Les carences dissociées en anticorps. A propos d'une observation d'infection à repetition par absence de $\beta_{2} \mathbf{M}$ et $\beta_{2} A$ globulines. Pediatrie, 19, 189.

Crabbe, P.A. \& Heremans, J.F. (1967) Selective IgAO deficiency with Steatorrhea. A new Syndrome. Amer. J Med. 42, 319.

GooD, R.A. \& ZACK, S.J. (1956) Disturbances in gammaglobulin synthesis. Pediatrics, 18, 109.

Gugler, E. \& Barandun, S. (1966) Les manifestations pulmonaires du syndromes de carence en anticorps. J. franc. med. Chir. Thorac. 20, 202.

Heremans, J. (1960) Les Globulines Seriques du Système Gamma; leur Nature et leur Pathologie. Arscia Bruxelles, Ed. Masson et Cie, Paris.

Heremans, J., Crabbe, P.A. \& Masson, P.L. (1966) Biological significance of exocrine gamma-A-immunoglobulin. Acta med. scand. Suppl. 445, 86.

Israĕl Asselain, R., Burtin, P. \& Chebat, J. (1960) Un trouble biologique nouveau: l'agammaglobulinémie avec $\mathrm{B}_{2}$-macroglobulinémie. Bull. Soc. med. Hôp., Paris, 76, 519.

Isrä̈l Asselain, R., Chebat, J., Uzzan, D. \& Derrida, J. (1966) Etude de 5 cas d'agammaglobulinémie avec manifestations broncopulmonaires. J. franç. med. Chir. Thorac. 20, 177.

LEVEQue, B. (1965) Les deficits en immuno-globulines chez l'enfant. Sem. Hôp., Paris, 12, 2191.

Marano, R., Pastore, G., Strada, C., Dammacco, F. \& Schiraldi, O. (1966) Sindromi di malassorbimento e di mielosi funicolare in un paziente con assenza di $\gamma$-A e $\gamma$-M immunoglobuline nel siero. Policlinico sez. Prat. 73, 1701.

Marie, J., Hennequet, A., JARLier, H., WATChI, J.M., Roux, Ch., Seguin, M. \& Richardet, J.M. (1965) Agammaglobulinémie congenital avec alymphocitose atrophie lymphoide et thymique. Sem. Hôp., Paris, 12, 2135.

Migueres, J., Layssol, M., Cabannes, R., De Boissezon, J.F., Bellan, Ch. \& Jeoffre, A. (1965) Agammaglobulinémie majeure, idiopathique avec splenomegalie considérable et adénopathies médiastinales. Presse Méd. 73. 241. 
Pena Guitian, J., Varela Bujan, J.M. \& Gomez Vidal, E. (1963) Sobre la patologia de las immunoglobulinas. Una revision, con aportacion de un caso de agammaglobulinemia por avsenci de las fracciones beta $2 \mathrm{~A}$ y beta $2 \mathrm{M}$. Rev. Esp. Pediat. 19, 223.

Pernod, J. \& Kermarec, J. (1966) Les agammaglobulinémies et leurs manifestations respiratoires. Presse Méd. 74, 2411.

Pernod, J., Saint Blancard, J., Raby, C., Reynier, C. \& MeyrueY, M.H. (1966) Les agammaglobulinémies de l'adulte et leurs manifestations pulmonaires. J. franc. med. Chir. Thorac. 20, 131.

Peterson, R.D., Cooper, M. \& Good, R.A. (1965) The pathogenesis of immunologic deficiency disease. Amer. Med. 38, 579.

Rockey, J.H., Hanson, L.A., Heremans, J.F. \& Kunkel,
H.G. (1964) Beta-2A aglobulinemia in two healthy men. J. Lab. clin. Med. 63, 205.

Rosen, F.S. \& Bougas, J.A. (1963) Acquired dysgammaglobulinemia; elevation of the 19S gamma-globulin and deficiency of the $7 \mathrm{~S}$ gamma-globulin in a woman with chronic progressive bronchectasis. New Engl. J. Med. 269, 1336.

Siguier, F., Betourne, Cl., Levy, R., Hartman, L., Guedon, J. \& RoBon, P. (1965) Les agammaglobulinémies dietes 'acquises' de l'adulte avec splénomégalie. Sem. Hop., Paris, 13, 784.

Werner, F.B., Asofsky, R., LidDy, T.J., TANAKa, Y., ROWE, D.S. \& FAHEY, J.L. (1965) An antibody deficiency syndrome. Selective immunoglobin deficiency with reduced synthesis of $\gamma$ and $\alpha$-immunoglobulin polypeptide chains. Amer. J. Med. 39, 319.

\section{Correspondence}

\section{Modern trends in leprosy}

SIR - The statement in the paper by Jamison (Postgrad. med. J., 1969, 45, 409): 'To-day in the United Kingdom no official figures are published . . . is incorrect, since from time to time such figures are published.

The latest figures were quoted in a ministerial reply to a question in the House of Commons on 27 November 1968, and quoted in Leprosy Review,
$1969,40,65$, as follows:

'By the end of 1967, 196 patients were reported to have been cured out of a total of 732 notified since 1951. Of the 357 patients remaining on the register at the end of 1967, 196 were known to be quiescent, but treatment was continuing as a precaution against recurrence.'
Consultant Adviser in Leprosy to the Department of Health and Social Security
S. G. BROWNE O.B.E., M.D., F.R.C.S., F.R.C.P. 